\title{
Fieldwork identities: introduction
}

By Ingie Hovland

When I left for fieldwork I was prepared for the possibility that the people I was going to study would probably have more facets to their identity than I had previously known. I was also aware that I needed to be careful not to attribute too rigid identities to them. I was not, however, prepared for the possibility that different people within the group would attribute a variety of different identities to me that I had not even thought of, and that this would affect the research process throughout fieldwork (and even post-fieldwork, as they responded to drafts of my writing).

The identities that are attributed to us and the roles we are placed in during fieldwork matter - to the people we study, to us, and to the research process. In this issue of Anthropology Matters, 11 authors reflect on fieldwork identities. Their reflections can be grouped loosely into three categories: reflections concerning perceived inequalities, differences or power relations, e.g. related to race or wealth; reflections concerning people's assumptions about the fieldworker based on the familiarity of his or her appearance, e.g. related to gender or age; and reflections concerning the negotiation that surrounds the role of "participant observer."

\section{Differences (e.g. race and wealth)}

Most of the people we come into contact with during fieldwork will not get to know us very well. They will form impressions of who we are based on the kinds of information they have access to, for example what we look like, our race, our clothing, and the types of accessories we carry around.

Michael Madison Walker describes some of his experiences doing research as a white man in rural Mozambique. He was variously assumed to be a priest, a development worker, a U.S. Peace Corps volunteer, and even a spy. In his article, he draws out how important it is to understand the historical and political context of a fieldwork site for example the various local historical connotations of "whiteness" - in order to understand how people perceive the fieldworker. However, he also describes how he was adopted as a fictive son in one Mozambican household. Joel Busher reflects on a similar situation of doing fieldwork as a white man in Namibia. His article centers on how people in the fieldwork site used him as an "identity prop", interpreting and appropriating his relations with others and themselves into their own local webs of relations and identities. Busher discusses whether his presence sometimes contributed to legitimising existing hierarchies, and whether it sometimes threatened his respondents' "impression management". He argues for a more careful ethical consideration of relationships in fieldwork. 
At first glance, one might think that the identity issues raised by Walker and Busher spring out of the perceived difference of their "whiteness" in Mozambique and Namibia. However, the next two authors show clearly that perceived differences and inequalities are not just tied to race, but to a set of more subtle impressions of the researcher related to clothing, accessories, and ways of talking.

Olumide Abimbola is a Nigerian, based at an academic institution in Germany, who carried out fieldwork among Nigerian traders in Benin. In his article he describes how the traders tried to work out who he was. Some thought his questions, his glasses and backpack made him a suspicious character or a spy; others thought he must be a German citizen (who could aid others in acquiring German visas). He argues that it was precisely the shared similarities between himself and the traders, i.e. their shared Nigerian background, that brought out the differences between them all the more sharply. The familiar brought out the unfamiliar. Ngambouk Vitalis Pemunta too describes his position as an "outsider within" during his fieldwork. Pemunta studied in Budapest and returned to his native Cameroon to do fieldwork. In addition, he was a man studying a presumed "female issue", namely female circumcision. Pemunta argues that the distinction between "insiders" and "outsiders" is too simplistic when conducting fieldwork, and that it is more helpful to think in terms of the "situated knowledges" of different people, including the fieldworker.

All the authors in this section mention that people around them during fieldwork assumed they must be especially wealthy or well-connected, even though they did what they could to counter this impression. Such assumptions brought expectations that they would be generous with gifts, favours and payments, and the implications of being seen as more wealthy remained with them throughout fieldwork.

\section{Familiarity (e.g. gender and age)}

Sometimes people relate to us on the basis of what they see as our familiarity. If the fieldworker is a young woman, for instance, some respondents may relate to her in certain ways because these ways are the familiar ways in which, in their view, one relates to a young woman.

Mariana Rios Sandoval turns her attention especially to the gendered aspects of interview dynamics. She discusses how her interviews with fathers in Mexico City were marked by the fact that these men were given a chance to talk about "personal" issues with a woman. While her experience in the interviews was overall positive, she touches on possible problems of cross-gender interviews raised by other authors, including the possibility that male respondents in certain settings might respond to a female interviewer on the basis of assumptions about women as passive listeners. Emilie Venables too examines gendered interview dynamics. She conducted fieldwork among "beach-boys" in Senegal, and quickly became aware of how much sexual tension pervaded her interviews with them. At the same time, she was aware that the "beach-boys" doubted her motives as much as she doubted theirs. In the presence of one respondent in particular she felt uncomfortable, and had to terminate the interview. She discusses the difficulties of balancing her loyalty to herself, to her informants, and to her research process.

David Poveda turns the discussion away from gender and towards the implications of his age and family. Poveda did fieldwork among children in Spain. He found that the presence of his own daughter played a role in his relationships with both the children 
he studied and with their parents. Other parents who saw him interact with his daughter were prepared to trust his interactions with their own children. They saw him as a trustworthy fellow parent. The other children, too, saw him as a parent. Poveda raises some of the ethical issues tied to letting one's children be part of one's research, but in conclusion argues that fieldworkers should not ban their children from playing a role during fieldwork.

\section{Negotiations: participant observation}

During fieldwork most ethnographers try to establish their role as that of "participant observer". Or, rather, they try to establish the dual and perhaps contradictory roles of "participant" and "observer". This can require a fair amount of negotiation - both with the surrounding people and with oneself.

Elizabeth Graveling studied members of churches in Ghana. Graveling is a member of a Christian church in England, but she quickly found that her own religious views and practices were sufficiently different from those of the people she studied that she continuously had to negotiate how to participate in their religious activities. She outlines how some of her fieldwork roles were shaped on "their" terms, and then discusses other aspects of her fieldwork identity that she tried to form on her own terms. She concludes that the role of participant observer is not a costume ready to be put on, but a mutually constructed role that the fieldworker does not have complete control over.

Katherine L. Smith discusses a particular incident during her fieldwork in Manchester, England, in which she was physically assaulted by a man in a social club. She discusses the difficulties of determining what the most appropriate response was to this assault, given her role as participant observer - a role that she did not want to jeopardise by responding like an "outsider" and calling the police. She argues that there is a fine balance between emotional involvement and "passionate detachment" in fieldwork, and that both form a part of the very fabric of research. The fragmentation of the self that this brings with it can be a useful way of becoming aware of one's own multiple, situated positionings.

Lucy Pickering too writes about the balance involved in retaining a sense of "herself" and at the same time learning new steps and taking on new identities during fieldwork. She describes how she learnt to improvise during ecstatic dance among "drop outs" in Hawaii. Once she had learnt this new practice, however, she was confronted with the question of whether she was actually learning to express herself in a new way (which is part of the point of ecstatic dance), or whether she was merely conforming to the people around her. She concludes that there is room for both perspectives, and that in fact they open up new insights into the sometimes conflicting views she held of the "drop out" world.

Barłomiej Walczak rounds off this section with some philosophical reflections on whether the fieldworker can, or ought, to fully integrate a "different" cultural perspective into his or her narrative. Through an extended discussion of Paul Stoller's work In Sorcery's Shadow, he describes how Stoller came to adopt Songhay cognitive categories to such an extent that in the end he did not translate them into researcher language. Instead, they came to dominate his perception of reality. Walczak argues that Stoller's example shows us some of the deep difficulties involved in mediating between experiencing "Otherness", and still retaining a researcher's perspective on 
the Other. The question, he concludes, is how "to see what an Other sees, but through our own eyes".

\section{New research}

Finally, this journal issue includes an article by Annika Launiala that does not fall under the theme of "fieldwork identities", but instead presents some of the methodological deliberations involved in her medical anthropology research. Launiala has conducted research on factors affecting treatment and prevention of malaria among pregnant women in Malawi. As part of this project, she administered a commonly used public health survey, namely a Knowledge, Attitudes and Practice (KAP) survey. In her article, she reflects critically on some of the problems she encountered when trying to interpret data from this survey, and some of the ways in which the survey can yield misleading impressions. She concludes by emphasising both the challenges and the value of working with researchers and tools from other disciplines, and encourages anthropologists to find appropriate ways of working in interdisciplinary teams.

\section{About the author}

Ingie Hovland completed a $\mathrm{PhD}$ in Social Anthropology at SOAS (University of London) in 2006, entitled Distance Destroys and Kills: An Anthropological Inquiry into the Nature of Faith in a Lutheran Norwegian Missionary Society. Her research interests include religion, sincerity, gender, historical anthropology, and ethnographic method. She is editor of the Anthropology Matters Journal and is happy to receive submissions to the journal for review - she can be contacted at ingiehovland@yahoo.co.uk 